\title{
PEMBERDAYAAN MASYARAKAT UNTUK MERINTIS KAMPUNG INGGRIS DI DESA KALIPAKEM KECAMATAN DONOMULYO KABUPATEN MALANG
}

\author{
Afif Ikhwanul Muslimin \\ Universitas Islam Negeri Mataram, Mataram, Indonesia \\ afifikhwanulm@uinmataram.ac.id
}

\begin{abstract}
Abstrak: Pertumbuhan ilmu pengetahuan, teknologi, dan ekonomi dunia yang cukup pesat, menyebabkan mobilisasi manusia semakin tinggi. Bergulirnya AFTA (Asia Free Trade Agreement) dan bergaungnya era revolusi industri 4.0 membuat masayarakat Indonesia harus memiiki daya saing Internasional. Sehingga, tujuan pengabdian masyarakat ini adalah meningkatkan kompetensi bahasa asing komunitas berbasis Desa dengan pembentukan kampung Inggris untuk meningkatkan daya saing masyarakat. Pengabdian ini dilaksanakan di Desa Kalipakem, Kecamatan Donomulyo, kabutapen Malang dengan metode PAR (Participatory Action Research). PAR adalah metode penelitian aksi partisipatoris, dengan tujuan untuk mengetahui masalah yang dihadapi subyek penelitian dan menjadikanya sebagai target untuk dipecahkan sesuai kebutuhan subjek yang diteliti. Pengabdian ini melibatkan tokoh penggerak masyarakat Desa Kalipakem dan masyarakat desa yang meliputi remaja dan ibu-ibu jamaah kemasyarakatan. Metode ini dilakukan untuk memahamkan masyarakat Donomulyo terhadap: a) kelemahan-kelamahan yang dialami dan dimilikinya, b) keinginan-keinginan masyarakat untuk mengatasi kekuranganya, c) menyusun strategi dan metode untuk memecahkan masalahnya dan d) membantu masyarakat mengatasi, memecahkan, dan menemukan jalan keluarnya. Berdasarkan implementasi pengabdian, diketahui bahwa 1) masyarakat Desa Kalipakem memberikan dukungan maksimal melalui antusiasme partisipasi dan pemfasilitasan kegiatan pengabdian, 2) materi pelatihan pengabdian yang sesuai dengan kebutuhan masyarakat mendorong antusiasme pelatihan bahasa Inggris, dan 3) optimisme keterwujudan kampung Inggris di Desa Kalipakem sangatlah tinggi yang ditunjukkan dengan keseriusan setiap pihak dalam mengikuti proses pengabdian.
\end{abstract}

Kata Kunci: kampung Inggris, Participatory Action Research, komunitas, desa

\begin{abstract}
The rapid growth of science, technology, and the world economy has caused human mobilization to increase. The implementation of the AFTA (Asia Free Trade Agreement) and the reverberation of the industrial revolution 4.0 require Indonesian people to boost international competitiveness. Thus, the aim of the present community service was to increase the international language competence in village-based communities by establishing English villages to increase community competitiveness. This program was carried out in the village of Kalipakem, Donomulyo sub-district, Malang using the PAR (Participatory Action Research). PAR is a participatory action research method which aims at finding out the problems faced by research subjects and making them targets to be solved according to the needs of the subjects being studied. It involved community leaders in Kalipakem Village and village communities, including teenagers and community worshipers. This method was utilized to make the community: a) understand experienced and possessed weaknesses, b) understand desires of the community to overcome weaknesses, c) develop strategies and methods to solve the problem, and d) help the community to overcome, to solve, and to find a way out. Based on community service implementation, it was found that 1) Kalipakem villagers provided maximum supports through the enthusiasm of participations and facilitating the community service activities, 2) dedicated training materials that fitted the needs of the community encouraged enthusiasm for English language training, and 3) optimism for the realization of the British kampung in the village of Kalipakem is very high shown by the seriousness of each party in following the activities.
\end{abstract}

Keywords: English village, Participatory Action Research, community, village 


\section{Pendahuluan}

Era kemajuan ilmu pengetahuan dan teknologi yang semakin pesat, semakin terbukanya kesempatan untuk berkomunikasi secara internasional, dan pelaksanaan pasar bebas menuntut bangsa Indonesia memiliki kompetensi yang kompetitif dalam segala bidang. Indonesia tidak bisa lagi hanya mengandalkan sumber daya alam dan kemampuan fisik untuk mencapai kesejahteraan bangsanya tetapi harus lebih mengandalkan sumber daya manusia yang profesional. Salah satu syarat untuk mencapainya adalah kemampuan berbahasa Inggris, khususnya untuk berkomunikasi, baik secara lisan maupun tertulis. Penguasaan bahasa Inggris sangat penting karena hampir semua sumber informasi global dalam berbagai aspek kehidupan menggunakan bahasa ini (Durand, 2006).

Penguasaan kemampuan berbahasa Inggris bagi masyarakat Indonesia saat ini sangatlah urgen. Hal ini berkaitan dengan bergulirnya kesepakatan negara-negara Asia untuk melaksanakan AFTA (Asia Free Trade Agreement) sejak 2015, bahkan sekarang era revolusi industri 4.0 sedang gencar-gencarnya digaungkan. Situasi ini memunginkan dengan mudahnya masyarakat luar negeri untuk masuk dan keluar ke negara Indonesia untuk meraup keuntungan dagang dari Negara Indonesia. Pasar bebas tersebut tentunya memberikan imbas penggunaan bahasa internasional yakni bahasa Inggris secara masif pada semua sector termasuk komunikasi lisan dan tulisan. Hal ini berarti bahasa Inggris mempunyai peran internasional dalam era globalisasi ini (Crystal, 2003).

Berkenaan dengan penguasaan bahasa Inggris, direktur eksekutif bidang akademik, Education First, Minh N. Tran dalam Koran Republika Online (12/6/2020) menyatakan "Tahun ini, Indonesia menduduki peringkat ke-51 dari 88 negara di dunia, dengan penurunan skor menjadi 51,58 dari 52,14 pada tahun lalu. Skor ini menempatkan Indonesia pada posisi ke-13 dari 21 negara di Asia dan berada di bawah nilai rata-rata kecakapan Bahasa Inggris kawasan Asia $(53,94) "$. Menurut laporan EF Proficiency Index, fakta ini berimplikasi pada daya saing ekonomi, perkembangan sosial dan inovasi (Koran Republika Online). Seperti yang disampaikan oleh Grace Candra Manager Wall Street Indonesia Kota Kasablanka, Jakarta, Selasa (4/9/2012) melalui media Koran Kompas (2012) bahwa kemampuan berbahasa Inggris itu penting bagi daya saing seseorang. Juga dengan kemampuan berbahasa Inggris yang baik, daya saing baik, maka akan meningkatkan daya saing Negara Indonesia.

Hasil penelitian yang dilakukan oleh Atsuyama (2008) menyatakan bahwa daya saing individu masyarakat Indonesia dalam hal penguasaan bahasa Inggris masih rendah. Fakta ini bisa menjadi cermin kompetensi bahasa Inggris sumber daya masyarakat desa dan perkampungan. Masyarakat yang lebih banyak melakukan kegiatan ekonomi di persawahan, pasar, dan berbagai sektor alam lainya tentunya pamor bahasa Inggris masih kalah jauh dibandingkan pentingnya kegiatan produktif pedesaan untuk bekerja. Padahal pedesaan ataupun perkampungan adalah pranata sosial yang cukup mendasar tempat terbentuknya jiwa sosial kemasyarakatan yang bisa menentukan karakter dan daya juang seseorang, khususnya bagi remaja kampung yang notabenya anak muda yang berjiwa dinamis, tentunya diharapkan dengan bergulirnya era AFTA dan jaman ramainya indrustri 4.0 para remaja kampung tersebut 
baik yang sudah memiliki basic bahasa Inggris maupun tidak bisa sama sekali, juga belum bisa mengaplikasikan kemampuan bahasa Inggrisnya dengan aktif. Oleh karena itu, pengajaran bahasa Inggris usia muda harus dilaksanakan untuk memberikan kesempatan kepada mereka untuk mempersiapkan diri bersaing dalam dunia global (Kubanek, 1998).

Dari uraian di atas dapat disimpulkan bahwa: 1) Pemerataan pembelajaran bahasa Inggris bagi daerah terpencil masih kurang, 2) Kampung adalah pranata sosial yang bisa membentuk karakter juang anak muda, 3) Penguasaan kompetensi bahasa Inggris bagi generasi muda sangatlah penting, 4) Pembiasaan bahasa Inggris di lingkungan Desa Kalipakem dalam bentuk English area masih belum ada, 5) Perlunya pembentukan lingkungan bahasa dengan pembiasaan dalam aktifitas sehari-hari, dan 6) Penggunaan pendekatan individual maupun pendekatan system dengan mempertimbangkan keberlanjutan program pendampingan melalui siklus pemberdayaan.

Beberapa pengabdian sebelumnya telah mengupayakan pengembangan penguasaan bahasa Inggris di kawasan pedesaan. Nuraziziah, dkk. (2019) menyatakan bahwa pelatihan bahasa Inggris untuk daerah wisata sangatlah bermanfaat, dan masyarakat menunjukkan antusiasme yang tinggi. Topik serupa ditemukan dalam pengabdian yang dilakukan oleh Tamrin \& Yanti (2019). Hasil pengabdianya menyatakan bahwa metode penguatan bahasa berbasis buku cerita ternyata sangat efektif untuk meningkatkan kemampuan bahasa Inggris. Susanti \& Rukiati (2017) juga menyimpulkan bahwa kegiatan penguatan bahasa di lingkungan desa sangatlah penting dan kegiatan pengabdian serupa perlu dilaksanakan di tempat lain. Menilik ketiga pengabdian yang ada, maka pengabdian yang bertujuan membentuk rintisan kampung Inggris ini sangatlah penting, mengingat perbedaan kondisi desa binaan yang bukan desa wisata. Masyarakat Desa Kalipakem membutuhkan pendapatan tambahan karena kekeringan di musim kemarau. Sehingga dengan pendekatan modul pelatihan yang berhubungan dengan kegiatan sehari-hari, masyarakat akan lebih antusias dan kemampuan bahasa Inggris masyarakat meningkat.

Kehidupan masyarakat pedesaan yang umumnya berkutat dengan dunia agraris, dengan karakteristik yang santun, menerima apa adanya, dan damai dengan kondisi yang ada disediakan oleh alam seringkali membuat pertumbuhan kesadaran akan perkembangan dunia modern menjadi minim atau bahkan tidak ada. Masyarakat Desa Kalipakem Kecamatan Donomulyo Kabupaten Malang mayoritas 95\% adalah petani dan keseharianya berangkat ke sawah dari pagi sampai sore membuat pola berfikir mereka cukup menggantungkan diri pada eksistensi sawah mereka. Hampir mayoritas generasi mudapun juga berpartisipasi membantu orang tua mereka untuk bekerja di sawah. Di samping itu, tak jarang pula berdasarkan dari hasil lulusan sekolah yang ada, kebanyakan anak muda di Desa Kalipakem tersebut belum berhasil menyelesaikan program pendidikan sembilan tahun. Hal ini dikarenakan bahwa kesadaran akan pentingnya pendidikan bagi persiapan generasi muda oleh orangtua yang menggantungkan kehidupanya di sawah masih sangat rendah.

Di sisi lain, letak geografis Desa yang berada di selatan salah satu bendungan besar di Kabupaten Malang, Bendungan Sutami, dimana area Desanya terlingkupi oleh hutan jati yang sangat lebat. Selain itu di sekitar Desa tidak ada peradaban modern perkotaan seperti halnya 
pusat perbelanjaan modern seperti mall, sekolah internasional, pusat bisnis, dan sarana pembawa modernisasi lain yang mungkin bisa membawa wawasan baru bagi masyarakat Desa guna melihat potensi persaingan yang lebih ketat. Ditambah lagi mobilitas warga yang terbatas hanya pada kegiatan agrarian dan pemenuhan kebutuhan yang sederhana dirasa cukup agar membuat warga Desa untuk tetap tinggal di Desanya. Sehingga, kesadaran akan persaingan dunia luar masih sangatlah minim.

Dilihat dari segi kebahasaan, mayoritas dan bisa dikatakan 99\% masyarakat di Desa Kalipakem tersebut menggunakan bahasa Ibu yaitu bahasa Jawa. Hal ini dikarenakan, sebagian besar masyarakatnya asli suku Jawa dan hanya segelintir berasal dari suku yang lain. Dalam keseharianya, bahasa Jawa menjadi jembatan penting komunikasi antar masayarakat dan bahasa ini dirasakan sudah sangat cukup memenuhi kebutuhan komunikasi berbahasa dengan lawan komunikasinya. Bahkan, ada juga beberapa warga masyarakat yang masih kurang lancar menggunakan bahasa Indonesia dalam berkomunikasi.

Sehubungan dengan penggunaan bahasa selain bahasa Jawa di Desa Kalipakem, generasi muda ataupun remaja hanya menggunakan bahasa Indonesai ketika mereka belajar di sekolah. Namun, tak jarang pula pada beberapa sekolah dan khususnya guru, cenderung lebih mengedepankan komunikasi bahasa kromo inggil dalam berkomunikasi di dalam proses belajar mengajar. Bahkan bahasa asing yang sangat popular dan menjadi bahasa internasional seperti bahasa Inggris, hanya menjadi muatan lokal di sekolah dan siswa hanya fokus pada pembelajaran grammar (struktur bahasa) yang lebih terkesan pasif dan bukan bahasa Inggris produktif untuk membantu komunikasi dalam kehidupan sehari-hari. Sehingga, bisa dikatakan bahwa kompentensi kebahasaan masyarakat Desa Kalipakem masih sangat rendah dalam hal penggunaan bahasa Indonesia. Bahkan sama sekali tidak ada dalam hal penggunaan bahasa Inggris.

Masyarakat Desa Kalipakem yang memang memiliki mobilitas keluar Desa cukup rendah, memang kebanyakan menganggap nilai urgensi penguasaan bahasa Inggris sebagai bahasa internasional sangatlah tidak perlu. Hal ini mungkin dikarenakan bahwa memang mereka tidak pernah bersinggungan dengan warga asing dari negara lain. Namun, mengingat potensi kedaerahan Desa Kalipakem ini dilihat dari segi topilogi yang indah dengan hamparan hijau yang memukau, ditambahlagi dengan dekatnya akses menuju bendungan Sutami, sudah barang tentu nantinya di era perdagangan bebas banyak potensi yang bisa digali secara bisnis dari Desa tersebut. Sehingga, dengan semakin cepat dan luasnya pertumbuhan dan mobilitas masyarakat asing baik dari negara tetangga maupun dari Negara barat maupun timur semakin tinggi, bahkan banyak program asing seperti pertukaran pelajar, kegiatan volunteer, dan kegiatan investasi dagang yang meningkatkan peluang bisnis masyarakat Desa Kalipakem. Dalam hal ini, tentunya cara pandang akan pentingnya bahasa asing bagi mereka perlu diselaraskan sesuai dengan kondisi persaingan dunia.

Masyarakat Desa Kalipakem Kecamatan Donomulyo Kabupaten Malang sangatlah kurang memiliki perhatian tinggi terhadap penguasaan dan penggunaan bahasa asing. Hal ini dapat ditunjukkan dengan frekuensi komunikasi masyarakat desanya yang sama sekali tidak pernah 
menggunakan bahasa asing. Juga, bisa dilihat dengan keberadaan penunjuk arah, denah, lokasi, maupun informasi desa yang semua tertulis dalam bahasa Indonesia.

Begitu pula dengan remaja-remaja yang ada di Desa Kalipakem, sekalipun sudah mempelajari bahasa Inggris hingga lulus sekolah dasar maupun sekolah lanjutan tingkat pertama, namun mereka belum mampu secara aktif berkomunikasi menggunakan bahasa Inggris. Bahkan, cara pandang remaja sebagai siswa-siswi sekolah, masih menganggap bahwa bahasa Inggris adalah mata pelajaran yang menakutkan atau sebagai momok yang sangat sulit untuk dipelajari. Hal ini menyebabkan, keinginan belajar dan menguasai bahasa Inggrispun menjadi sangat minim atau bahkan tidak ada. Tak jarang bahasa Inggris menjadi kurang populer dikalangan remaja di desa tersebut.

Dilihat dari segi generasi, setidaknya remaja sebagai generasi muda di Desa Kalipakem masih mengenal bahasa Inggris, akan tetapi bagi generasi tua ataupun orangtua, bahasa Inggris adalah bahasa asing yang benar-benar asing. Bahkan para orangtua tidak ada yang bisa berkomunikasi aktif dengan bahasa Inggris. Ditambah pula, persepsi belajar bahasa Inggris sebagai bahasa asing yang hanya bisa dipelajari melalui sekolah atau bangku di kelas, membuat persepsi penguasaan bahasa asing tersebut sulit dilakukan.

Disisi lain, lembaga pendidikan non-formal sepertihalnya TPQ dan kegiatan keislaman di masjid, masih kurang merespon urgensi dari penguasaan bahasa Asing tersebut. Seperti halnya di TPQ di Desa Kalipakem, disana tidak diajarkan bahasa Inggris. Juga para remaja masjid yang seringkali mengadakan kegiatan pembinaan keagaaman tidak pernah pula menekankan pentingnya bahasa asing. Sedangkan lembaga non-formal tersebut potensial untuk menyadarkan, meningkatkan, dan membelajarkan bahasa asing untuk bekal remaja dan generasi muda Islam di masa yang akan datang.

Sehingga dapat disimpulkan hubungan antara kondisi masyarakat Desa Kalipakem dengan kemampuan berbahasa Inggris adalah: 1) Kondisi geografis masyarakat membuat mereka sedikit terisolasi dari perkembangan peradaban modern yang berimplikasi pada aspek pengenalan bahasa, 2) Kesadaran pentingnya bahasa Inggris sangatlah minim atau bahkan tidak ada, 3) Sekalipun remaja di Desa Kalipakem pernah belajar bahasa Inggris hingga SLTP, akan tetapi tidak ada yang mampu berkomunikasi secara aktif, 4) Cara pandang belajar bahasa Inggris bagi remaja dan generasi tua menjadi penghambat keberhasilan mereka dalam belajar bahasa Inggris, 5) Tidak adanya lingkungan yang mendukung penggunaan atau praktik bahasa Inggris, 6) Pendidikan non-formal yang potensial guna mempopulerkan bahasa Inggris kurang dimanfaatkan, dan 7) Masyarakat Desa Kalipakem tidak bisa berbahasa Inggris lisan aktif.

Berdasarkan fenomena di atas, dan mengingat kultur masyarakat Desa Kalipakem yang sangat beragam dengan rentan usia yang beragam pula, maka perlu dilakukan penelitian action research dalam bentuk pengabdian untuk mengontrol, mendorong, dan mengarahkan perilaku dan sikap mereka, karena kampung adalah salah satu pranata sosial terpenting pembentuk daya juang remaja atau anak muda juga sebagai pemegang estafet perjalanan kehidupan ini, khususnya dalam mempersiapkan diri dalam era persaingan global dengan masyarakat Negara lain. Oleh karena itu, pengabdian masyarakat dalam bentuk perintisan kampung Inggris yang diawali dengan model pemberdayaan masyarakat khususnya remaja masjid dan umum di Desa 
Kalipakem Kabupaten Malang ini perlu dilakukan sebagai tanggung jawab moral peneliti sebagai bagian dari universitas dalam rangka pelaksanaan Tri Dharma Perguruan Tinggi.

\section{Metode}

Dalam rangka mengubah kondisi masyarakat Desa Kalipakem Kecamatan Donomulyo Kabupaten Malang yang sama sekali kurang memahami pentingnya bahasa Inggris dan tidak satupun keberadaan lingkungan yang memberdayakan kemampuan bahasa Inggris, akan digunakan metode PAR (Participatory Action Research). Metode ini dilakukan untuk memberikan pemahaman masyarakat Donomulyo terhadap: a) kelemahan-kelemahan yang dimiliki, b) keinginan masyarakat untuk mengatasi kekurangan dan kelemahannya, c) menyusun strategi dan metode untuk memecahkan masalahnya dan d) membantu masyarakat mengatasi, memecahkan, dan menemukan jalan keluarnya.

Metode PAR ini digunakan untuk tidak membuat masyarakat dampingan sebagai obyek, tetapi menjadikannya sebagai subyek penelitian. Masyarakat sendiri yang memahami, menginginkan, dan memecahkan permasalahan yang mereka hadapi. Posisi peneliti sebagai fasilitator bagi masyarakat untuk mencapai cita-citanya dan memberikan jalan keluar dengan merumuskan strategi yang dapat digunakan masyarakat untuk mengatasi permasalahan mereka. Perumusan jalan keluar dan strategi ini tetap melibatkan masyarakat dengan harapan apabila masyarakat mengalami masalah sosial, mereka bisa memecahkan permasalahan mereka sendiri tanpa bantuan orang lain.

Dengan PAR ini bermanfaat untuk memfasilitasi dan memotivasi agar masyarakat khususnya kalangan remaja mampu:

1. Mengidentifikasi kekuatan dan kelemahan kemampuan bahasa masyarakatnya.

2. Menemukenali faktor penyebab problematika kebahasaan masyarakat dan alternative solusinya.

3. Menyusun strategi dan metode yang tepat untuk memecahkan permasalahan kebahasaan di lingkungan sekitar.

4. Menyusun rencana aksi berdasarkan prioritas dan keberlanjutan program melalui tahapantahapan hingga mencapai target yang diharapkan.

Ada enam prinsip PAR seperti yang digambarkan oleh Winter (1989) dalam bukunya Learning from Experience, dengan deskripsi sebagai berikut:

1) Refleksi kritis. Kebenaran adalah sesuatu yang ditemukan di lapangan dan tidak bersifat mutlak. Sehingga dalam pengabdian ini, peneliti mengamati secara langsung kondisi lingkungan Desa Kalipakem dan menggali permasalahan serta potensi desa dan menganalisanya secara teoritis.

2) Dialektika kritis. Keberadaan peran dialog santai bersama masyarakat desa menjadi sarana penting dalam menjalin komunikasi sosial dan mental demi keberhasilan pengabdian. Oleh karenanya, peneliti melakukan dialog dengan tokoh penggerak dan beberapa warga agar tercipta ide untuk mencapai tujuan pengabdian. 
3) Kolaborasi sumber daya. Masyarakat desa tempat mengabdi memiliki potensi dan sama halnya dengan peneliti yang juga berperan sebagai partisipan. Melihat potensi tersebut, peneliti memanfaatkan semangat warga yang antusias mengembangkan diri dan desanya melalui penguasaan bahasa Inggris, untuk merangkul masyarakat yang belum terlibat.

4) Kesadaran resiko. Munculnya ide pengabdian bisa jadi menjadi ancaman bagi tatanan masyarakat desa yang sudah ada. Peneliti melihat bahwa komunikasi yang baik akan membantu menenangkan masyarakat akan ketakutan terhadap hal tersebut. Oleh karenanya, dilaksanakan komunikasi secara informal dengan masyarakat beberapa kali.

5) Struktur plural. Pluralisme akan cara pandang terhadap sebuah ide tentunya muncul dalam pelaksanaan pengabdian. Peneliti melihat hal ini sebagai faktor pendukung adanya perubahan ke arah yang diharapkan. Dalam prinsip peneliti, komentar apapun mengenai kegiatan pengabdian di Desa Kalipakem adalah wujud perhatian yang baik dari warga dan untuk kemanfaatan bersama.

6) Teori, praktik, dan transformasi. Teori dalam pandangan para ahli akan menjadil landasan informasi untuk melaksanakan praktek. Praktik dalam posisi sebaliknya juga berperan sebagai penyempurna teori yang ada untuk menciptakan transformasi berkelanjutan. Dalam hal ini, peneliti selalu mengakulturasikan teori penelitian yang ada dan segala pengalaman praktik pengabdian di Desa Kalipakem.

PAR terdiri dari tiga kata yang selalu berhubungan seperti daur (siklus), yaitu partisipasi, riset, dan aksi (Modul KKN IAIN Sunan Ampel Surabaya, 2008). Artinya hasil riset yang telah dilakukan secara partisipatif kemudian diimplementasikan ke dalam aksi. Aksi yang didasarkan pada riset partisipatif yang benar akan menjadi tepat sasaran. Sebaliknya, aksi yang tidak memiliki dasar permasalahan dan kondisi subyek penelitian yang sebenarnya akan menjadi kontraproduktif. Namun, setelah aksi bukan berarti lepas tangan begitu saja, melainkan dilanjutkan dengan evaluasi dan refleksi yang kemudian menjadi bahan untuk riset kondisi subyek penelitian setelah aksi. Begitu seterusnya hingga kemudian menjadi sesuatu yang ajeg (konsisten). O'Brien (2001) menggambarkan proses riset aksi dalam bentuk model siklus seperti spiral. Setiap siklus memiliki empat tahap, yaitu rencana, tindakan, observasi, dan refleksi. Berikut adalah deskripsi tahapan pengabdian yang telah dilaksanakan:

a. Perencanaan. Dalam tahap ini rencana dibuat setelah memperhatikan kondisi riil masyarakat dengan menggunakan analisis SWOT. Dalam menganalisis problematika di masyarakat dan menganalisis kekuatan, kelemahan, peluang, dan ancaman yang terjadi di masyarakat ini dilakukan dengan melibatkan masyarakat di Desa Kalipakem. Perencanaan ini meliputi strategi dan metode dalam memecahkan problematika kebahasaan yang dihadapi oleh masyarakat Donomulyo.

b. Tindakan. Setelah proses perencanaan dilakukan, masyarakat Donomulyo mengimplementasikan rencana yang telah dibuat dengan difasilitatori oleh peneliti. Bentuk kegiatan yang akan dilakukan dalam penelitian action research yang terdiri dari: Focus Group Discussion (FGD) untuk mengakomodir kebutuhan dan permasalahan masyarakat, pelatihan secara berkala berdasarkan program kegiatan yang telah ditetapkan, dan penyusunan modul pendampingan pengembangan bahasa Inggris untuk sehari-hari. Seluruh proses dan siklus 
kegiatan dilakukan oleh subyek pengabdian dan peneliti, diobservasi, dimonitoring dan evaluasi. Atau dengan kata lain, secara mudah menurut Susanti \& Rukiati (2017) tahapan action meliputi kegiatan sosialisasi, pelatihan, pendampingan, serta evaluasi guna keberlanjutan

c. Observasi. Pengamatan dilakukan untuk memperhatikan dan menganalisis keberhasilan, kelemahan, dan kekurangan strategi dan metode yang digunakan dalam menyelesaikan problematika yang terjadi di masyarakat.

d. Refleksi. Usaha yang telah dilakukan dalam memecahkan problematika di masyarakat Donomulyo tersebut direfleksikan dan dievaluasi, baik kekurangan, kelemahan, dan keberhasilan strategi dan metode dalam memecahkan problematika kebahasaan masyarakat tersebut. refleksi dan evaluasi ini berujung kepada perencanaan ( $p / a n$ ) seperti pada poin pertama untuk menuntaskan problematika kebahasaan masyarakat, baik yang belum tuntas pada tahap pertama atau untuk memecahkan problematika yang baru hingga masyarakat Donomulyo yang mampu menggunakan bahasa Inggris dalam kehidupan sehari-hari untuk mewujudkan rintisan kampung Inggris.

\section{Hasil dan Pembahasan \\ Deskripsi FGD}

Tahap persiapan pelaksanaan program perintisan kampung Inggris di Desa Kalipakem Kecamatan Donomulyo Kabupaten Malang dimulai dengan koordinasi yang baik dengan pihak terkait khususnya tokoh masyarakat Desa Kalipakem agar dapat mengarahkan dan membimbing masyarakat desa untuk mengikuti program tersebut. Oleh sebab itu, peneliti bersama tokoh penggerak masyarakat Desa Kalipakem mengadakan workshop singkat sebagai upaya koordinasi program penelitian ini. Workshop dimulai dengan pemaparan maksud dari peneliti kepada tokoh masyarakat dan warga. Setelah diperoleh kesepakatan dengan peserta koordinasi, langkah selanjutnya adalah pembahasan teknis pelaksanaan kegiatan sosialisasi program secara umum pada masyarakat Desa dan pendampingan pelatihan dasar bahasa Inggris.

Koordinasi yang dilakukan peneliti bersama tokoh desa dan warga Desa Kalipakem menghasilkan beberapa keputusan teknis sebagaimana berikut:

1. Waktu pelaksanaan pendampingan akan ditentukan bersama calon peserta pemberdayaan bahasa Inggris pada saat sosialisasi program.

2. Sehubungan dengan pelaksaan pendampingan pelatihan, peserta akan digolongkan sesuai dengan tingkat kemampuan kebahasaan, yaitu: pemula, menengah, dan lancar. Dimana aspek penilaian difokuskan pada penguasaan kemampuan berbicara berbahasa Inggris.

3. Materi yang digunakan sebagai pemicu semangat berbahasa Inggris adalah ekspresi berbahasa Inggris yang mudah dan bisa digunakan sebagai jembatan komunikasi seharihari. Sebagai contoh adalah ucapan dalam sapaan, ekspresi jual beli, dll.

4. Demi keberlanjutan program, telah disepakati bahwa di desa tersebut akan ditunjuk pioneerpioner yang berbakat dalam bahasa Inggris yang bisa menggerakkan semangat penggunaan 
bahasa Inggris di lingkungan Desa Kalipakem. Juga peneliti akan melakukan pendampingan secara kontinu guna menjaga semangat membudayakan bahasa Inggris.

Di sore hari kegiatan koordinasi dan workshop persiapan perintisan kampung Inggris selesai dan peneliti kembali guna mempersiapkan aksi di kegiatan sosialisasi dan siklus I yang sudah direncanakan.

\section{Deskripsi Siklus I}

Pada hari implementasi siklus I, peneliti sudah tiba di rumah salah satu tokoh penggerak masyarakat di desa tersebut. Sesuai dengan rencana, warga yang berminat mengikuti program, akan hadir pada pukul 14.00 WIB. Setelah berkoordinasi singkat dan melakukan persiapan teknis kegiatan, para peserta datang dengan antusiasme.

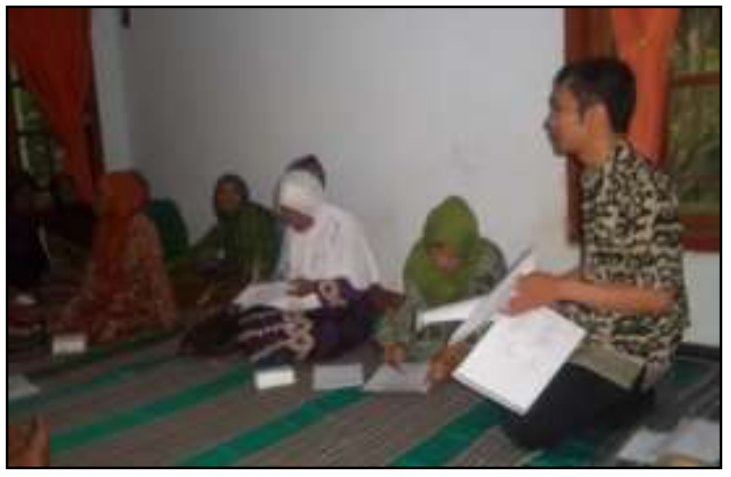

Gambar 1. Penjelasan mekanisme pelatihan bahasa Inggris kepada ibu-ibu jama'ah

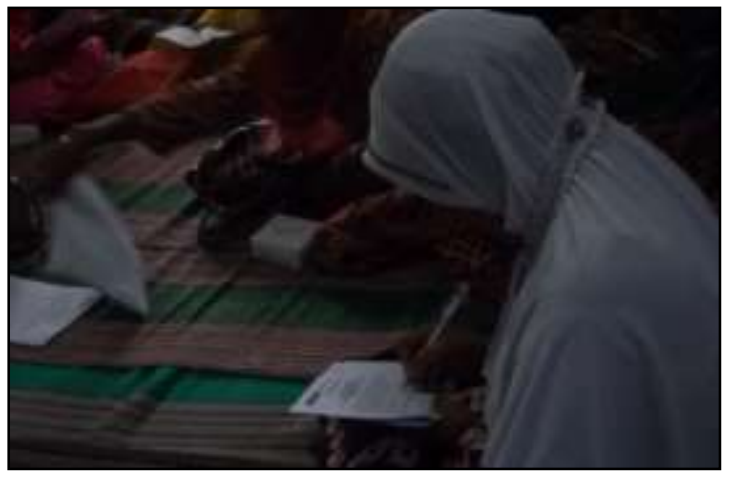

Gambar 2. Calon peserta mengisi form analisa kebutuhan PAR

Program pelatihan dibuka oleh salah satu tokoh masyarakat desa dan pemberian motivasi serta sosialisasi program rintisan kampung Inggris. Untuk menunjang tujuan program rintisan kampung Inggris ini, peneliti membagikan angket sebagai analisa kebutuhan masyarakat akan perlunya pembentukan kampung Inggris. Meskipun tidak semua peserta yang datang mengisi angket dikarenakan banyak juga yang sudah berusia lanjut diatas 60 tahun, lebih dari 50\% peserta mengisi angket. Hasil angket disajikan pada Grafik 1.

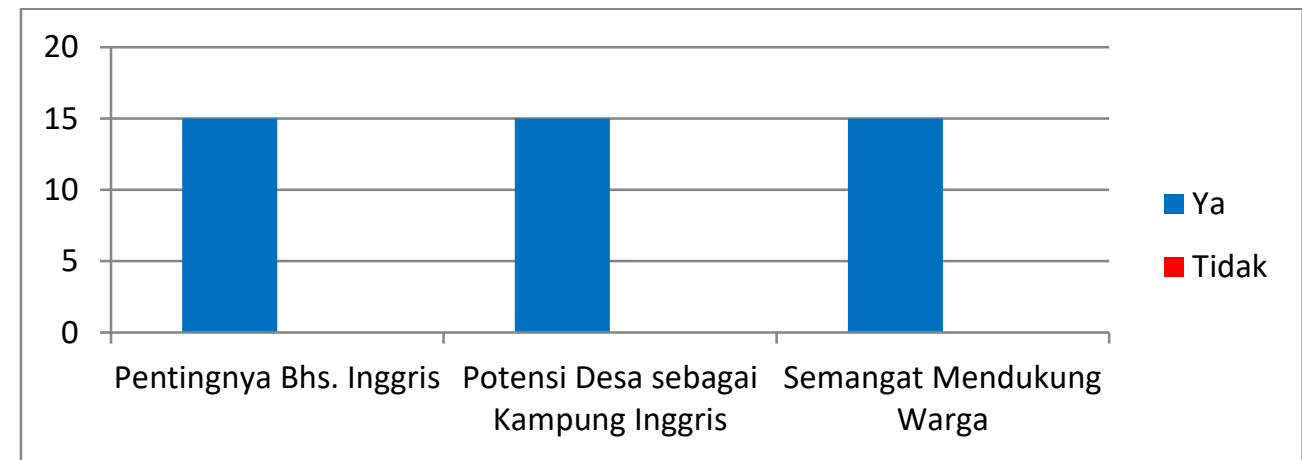

Grafik 1. Hasil Angket Persepsi Masyarakat Desa Kalipakem terhadap Pentingnya Bahasa Inggris, Potensi, dan Dukungan Masyarakat Desa sebagai Kampung Inggris

Berdasarkan hasil kuesioner, dapat diketahui bahwa persepsi masyarakat sungguh memuaskan, dikarenakan semua responden menyatakan sangat bersemangat mengikuti program tersebut karena semua merasa bahwa bahasa Inggris sangatlah penting dan semua 
yakin bahwa kampung Inggris bisa terwujud di Desa Kalipakem. Mengingat hasil angket yang memuaskan tersebut, kemudian peneliti juga menggali motivasi yang mendasari dukungan masyarakat Desa Kalipakem untuk mewujudkan kampung Inggris di desanya.

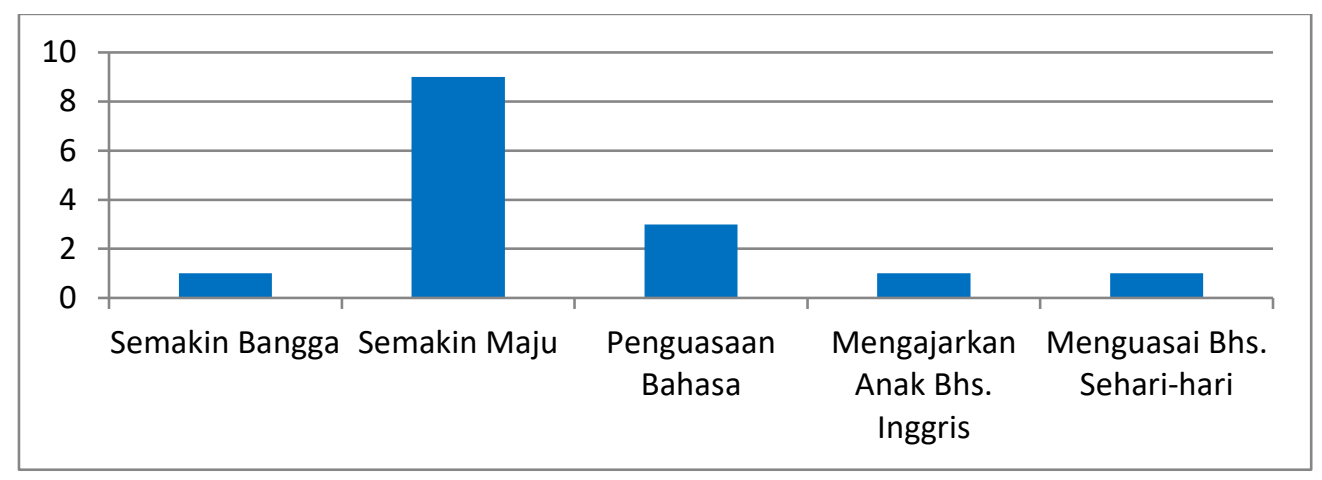

Grafik 2. Hasil Angket Motivasi Dukungan Masyarakat Desa kalipakem

Grafik 2 menunjukkan data statistik alasan mengapa masyarakat Desa Kalipakem memberikan dukungan tinggi akan program pengabdian perintisan kampung Inggris ini. Alasan utama masyarakat adalah karena mereka akan merasa senang bilamana desanya semakin maju. Majunya desa tentunya akan berpengaruh pada beranekaragam perbaikan diberbagai hal seperti infrastrktur desa, perputaran ekonomi desa semakin cepat, dan lebih banyak orang luar desa mengenal Desa Kalipakem. Di peringkat kedua, motivasi masyarakat desa mendukung program pengabdian ini adalah karena mereka ingin menguasai bahasa Asing. Tiga reponden menyatakan bahwa di era sekarang bahasa Inggris menjadi media penting untuk bisa berkomunikasi dengan tamu asing. Sedangkan motivasi umum yang menjadi latar belakang dukungan masyarakat adalah karena kebanggaan akan meningkat jika desa mereka menjadi kampung Inggris, mereka bisa menguasai ekspresi komunikasi berbahasa Inggris sehari-hari, dan mampu mengajarkan bahasa Inggris kepada anaknya.

Setelah diketahui dukungan dan motivasi masyarakat desa akan pelaksanaan pengabdian ini, peneliti juga menggali informasi kompetensi kebahasaan Inggris masyarakat Desa Kalipakem melalui angket yang sama. Melalui angket tersebut ditemukan bahwa seluruh responden menyatakan kurang lancar berkomunikasi dengan bahasa Inggris. Hasil angket ditunjukkan pada Grafik 3.

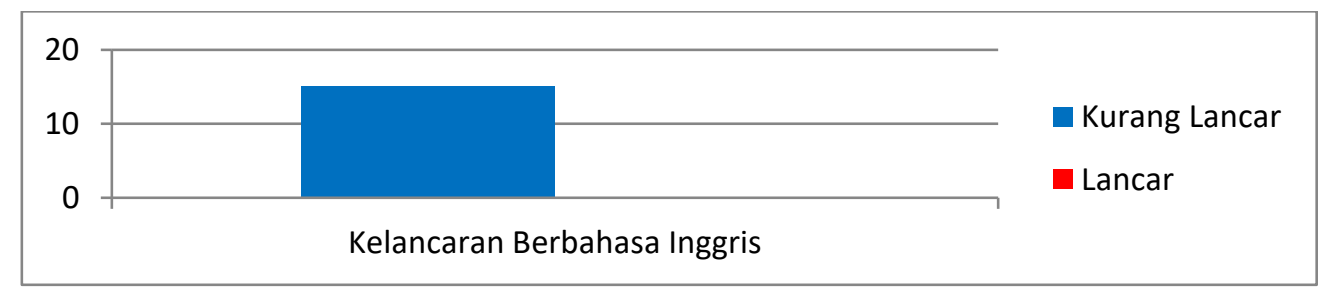

Grafik 3. Hasil Angket Kelancaran Berbahasa Inggris Masyarakat Desa Kalipakem

Sebanyak 13 responden mengatakan bahwa mereka belajar bahasa Inggris disaat mereka sedang mengajarkan bahasa Inggris kepada anaknya. Hal ini menunjukkan aktifitas keluarga bisa menjadi media motivasi dan transfer bahasa. Hasil ini dapat dilihat di Grafik 4. 


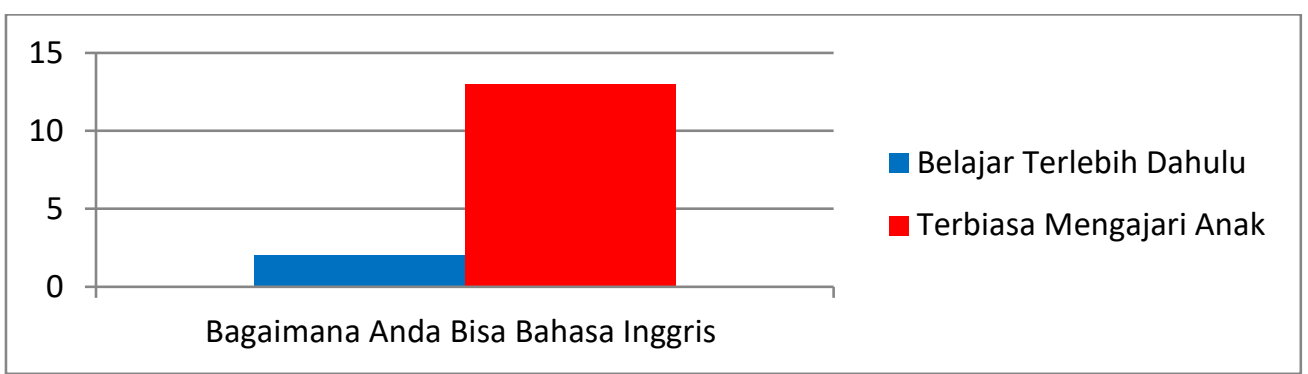

Grafik 4. Hasil Angket Sumber Kompetensi Bahasa Inggris Masyarakat Desa Kalipakem

Setelah kegiatan sosialisasi selesai dan peserta faham akan tujuan dan manfaat dari program tersebut, peneliti melanjutkan rencana untuk melaksanakan siklus I. Seperti dalam rencana hasil koordinasi awal maka materi yang disampaikan adalah ekspresi-ekspesi sapaan dan yang biasa digunakan dalam kehidupan sehari-hari khususnya dilingkungan rumah. Hal ini karena target utama komunikasi lisan dalam bahasa Inggris adalah agar lawan bicara memahami apa yang dibacarakan (Husein \& Dewi, 2019). Karena konteks dari topik pelatihan bisa dipahami dengan mudah.

Metode pelatihanya diawali dengan drilling dan pembiasaan pengucapan ekspressi bahasa Inggris. Ternyata, semua peserta mengikuti instruksi peneliti dan mengulangi pengucapanya dengan penuh semangat dan lantang. Sehingga, hanya butuh waktu sebentar para peserta sudah berhasil menggunakan ekspresi sapaan tersebut tanpa bantuan teks kepada teman peserta pelatihan lainya.

Setelah itu, peserta diminta berlatih berkomunikasi dengan teman peserta lainya menggunakan ekspresi dialog yang biasa diucapkan ketika dirumah. Bersyukur kepada Allah SWT, ternyata dengan modal semangat peserta, tidak hanya anak-anak, dewasa, maupun orang tua mampu berkomunikasi singkat dengan konteks memperkenalkan diri, mengenal orang baru, dan komunikasi di rumah. Berdasarkan hasil evaluasi peneliti, dapat disimpulkan bahwa semangat belajar masyarakat Desa sangatlah tinggi. Meskipun, peimilihan materi modul yang lebih mengena dalam konteks Indonesia sangatlah diperlukan guna mempermudah peserta memahami dan mengaplikasikanya. Sehingga, pukul 17.00 WIB program sosialisasi dan siklus I diakhiri dengan berdoa bersama.

\section{Deskripsi Siklus II}

Seminggu kemudian, peneliti berencana melanjutkan pembinaan rintisan kampung Inggris di Desa Kalipakem. Peneliti berangkat dan langsung menuju rumah salah satu tokoh masyarakat desa. Setelah berdialog singkat, akhirnya tim bersama beliau berangkat bersama menuju kediaman salah satu warga yang ditempati untuk kegiatan jamaah yasin dan istighosah. Momen jamaah tersebut memang sangat tepat dikarenakan bisa digunakan sebagai sarana silaturahim dan mengumpulkan warga guna pelaksanaan siklus II program tanpa harus bersusah payah mengumpulkan warga.

Sesampainya di rumah warga, tim menyampaikan kembali bahwa ini adalah siklus II program rintisan kampung Inggris dan jamaah berbahagia menyambutnya. Untuk siklus II ini, tim telah menyiapkan materi pendampingan yaitu bagaimana peserta bisa menyampaikan harga 
barang dalam bahasa Inggris dan bagaimana peserta mampu melakukan transaksi jual beli dengan menggunakan bahasa Inggris.

Dalam pelaksanaanya, tim mebagikan modul belajar yang berisi ekspresi yang digunakan dalam jual beli. Kurang lebih sama dengan siklus I, tim men-drill peserta pendampingan siklus II dengan meminta mereka mengikuti cara pengucapak ekspresi tersebut yang dimulai dengan pembiasaan pengucapan angka dan nilai uang. Selanjutnya, peserta diminta melakukan hal yang sama pada ekspresi dalam jual beli barang di pasar dan toko modern. Seperti yang terlihat pada semangat peserta pendampingan, hasilnya sungguh luar biasa, peserta mampu menanyakan barang yang mereka butuhkan, bertanya harganya, menawar barang tersebut, dan menJawab pertanyaan pembeli sambil menyebutkan harga yang disepakati. Hal tersebut menunjukkan bahwa, minat dan keyakinan masyarakat Desa Kalipakem untuk mewujudkan kampung Inggris sangatlah besar dan dukungan mereka kepada peneliti sangatlah tinggi. Bahkan seorang nenek yang berusia diatas 60 tahun selalu menyapa kami dengan bahasa Inggris, meminta kami mengunjunginya dalam bahasa Inggris, dan menyebutkan harga barang dalam bahasa Inggris.

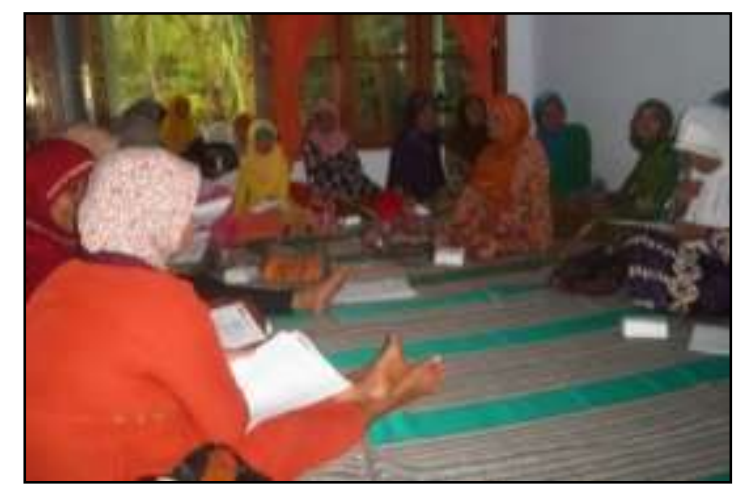

Gambar 3. Peserta berlatih mengucapkan ekspresi jual beli dalam bahasa Inggris

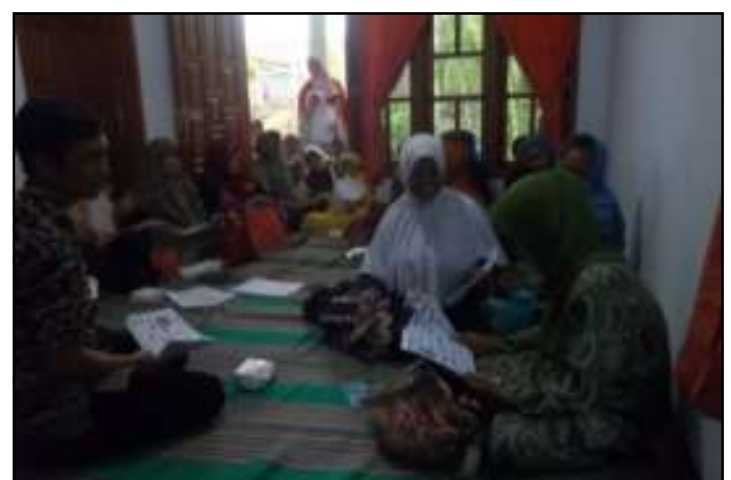

Gambar 4. Peserta PAR dengan antusias berbahasa Inggris

Dari hasil evaluasi peneliti, dapat diketahui bahwa kendala pembiasaan bahasa Inggris dari hasil siklus II adalah beberapa peserta masih malu menggunakan bahasa Inggris dikarenakan masih belum mampu mengucapkan dengan benar. Keunggulan siklus II, materi jual beli yang sangat familiar dengan kebiasaan sehari-hari warga menjadi katalis yang mempercepat penguasaan bahasa Inggris bagi peserta. Juga, suasana pendampingan yang humanis dan tidak bersifat klasikal atau tiadanya batas antara peneliti dengan peserta membuat peserta rileks menggunakan bahasa Inggris. Pada akhirnya, pendampingan siklus II berakhir dengan hasil positif dan diakhiri dengan doa bersama.

\section{Keberlanjutan Program}

Program-program yang telah kami laksanakan diharapkan bisa dilanjutkan oleh masyarakat Desa Kalipakem secara mandiri. Selanjutnya, kami harapkan bisa menjadi contoh bagi desa-desa yang lain di Kecamatan Donomulyo Kabupaten Malang. Di bawah ini peneliti mencoba menjelaskan keberlanjutan program diantaranya: 
1. Dalam bidang keilmuan. Penguasaan bahasa Inggris oleh masyarakat Desa Kalipakem akan menjadikan nilai kebanggaan tersendiri bagi masyarakatnya dibandingkan dengan masyarakat Desa lain dan pastinya mampu membuka peluang kegiatan usaha lainya. Terbukti dengan antusiasme partisipasi masyarakat belajar bahasa Inggris dikarenakan memahami kemanfaatanya (Tamrin \& Yanti, 2019). Disamping pula, setiap masyarakat pada akhirnya menjadi agen yang berkontribusi pada pertumbuhan masyarakat sebagai wujud tugas kemasyarakatan (St. Syamsudduha \& Tekeng, 2017)

2. Dalam bidang usaha. Seiring dengan pesatnya dan memasyarakatnya penggunaan bahasa Inggris di Desa Kalipakem, maka kepercayaan masyarakat luar Desa dan umum akan semakin meningkat untuk menimba ilmu dan melatih kemampuan berbahasa Inggris di Desa Kalipakem. Sehingga bisa menjadi lading usaha kursus bahasa Inggris ataupun penyedia sarana penginapan, bahkan juga usaha makanan dan minuman, guna mememnuhi kebutuhan para pengguna jasa kampung Inggris di Desa Donomulyo

3. Dalam bidang pariwisata. Dengan semakin tingginya intensitas produksi pertanian daerah yang telah berhasil merambah beberapa wilayah di Indonesia, bilamana ditunjang dengan promosi dan sosialisasi yang menggunakan bahasa Inggris, maka bisa diproyeksikan suatu saat nanti Desa Kalipakem akan mampu menjadi salah satu tujuan wisata bisnis sambil mengembangkan bahasa Inggris. Bahkan menjadi tujuan tamu asing untuk belajar berwiraswasta dengan pengantar bahasa Inggris.

4. Dalam bidang pendidikan. Sejalan dengan program pemerintah yang tergabung dalam era AFTA dan era revolusi industri 4.0 dimana nantinya seluruh komponen masyarakat termasuk para pelajar harus mampu berbahasa Inggris aktif, maka kampung Inggris yang diharapkan terus berkembang dan berkelanjutan ini mampu memperkuat kompetensi bahasa Inggris pelajar yang dipelajarinya di sekolah. Hal ini menunjukkan bahwa msayarakat di Desa Kalipakem dengan kompetensi bahasa Inggris yang dimiliki menjadi lebih bisa memperkenalkan apa yang mereka miliki kepada dunia luar (Handayani, 2016).

Guna mencapai keberlanjutan program kampung Inggris di Desa Kalipakem ini maka ditempuhlah beberapa langkah yang akan dilaksanakan:

1. Pemantauan pelaksaan program pemberdayaan bahasa Inggris oleh pioneer dan penggerak Desa. Pioneer atau warga yang sudah dilatih oleh peneliti, secara berkala melakukan pengayaan bahasa setiap hari minggu bersama penggerak desa. Kegiatan pemantuan berfungsi meningkatkan semangat belajar bahasa dan semakin memperkaya kosakata berbahasa Inggris.

2. Pendampingan perkelanjutan oleh peneliti sehubungan dengan penguatan kompetensi kebahasaan melalui komunikasi seluler setiap dua minggu sekali dan dua bulan sekali melalui kunjungan langsung. Kemudian, setelah Desa Kalipakem sudah berhasil mandiri, kunjungan langsung peneliti dihentikan. 


\section{Kesimpulan}

Berdasarkan hasil penelitian yang sudah dilaksanakan, maka dapat disimpulkan bahwa masyarakat Desa Kalipakem Kecamatan Donomulyo Kabupaten Malang mendukung sekali program perintisan Kampung Inggris dengan wujud semangat, antusiasme, dan keyakinan tinggi. Bukti dukungan masyarakat ini diwujudkan dengan semangat mengikuti sosialisasi, pendampingan I dan II, dan penggunaan ekspresi bahasa Inggris yang telah dipelajari paska pendampingan. Kemudian, pemilihan materi modul yang mengambil tema masyarakat Indonesia dalam kehidupan sehari-hari ternyata sangat memicu suksesnya pembelajaran bahasa Inggris bagi masyarakat lingkungan Desa Kalipakem.

Dilihat dari sisi geografis, mengingat kondisi lingkungan yang masih alami dan belum tertata sebagai desa wisata, pengabdian selanjutnya bisa menyasar bidang pengembangan pariwisata alam sebagai penguat fungsi kompetensi bahasa Inggris yang telah dikuasai. Sehingga sirkulasi ekonomi Desa Kalipakem semakin meningkat dan mensejahterakan masyarakat Desa.

\section{Ucapan Terima Kasih}

Penulis dan tim pengabdian mengucapkan terima kasih kepada: 1) Bapak Nur Wachid selaku tokoh penggerak remaja Desa Kalipakem yang telah membantu koordinasi dan komunikasi dengan masyarakat Desa Kalipakem, 2) Ibu-ibu jamaah tahlil dan istighosah, serta masyarakat Desa Kalipakem yang mendukung dan berpartisipasi belajar bahasa Inggris, dan 3) Bapak Langgeng Budianto yang telah memberikan dukungan akomodasi pengabdian.

\section{Referensi}

Atsuyama. (2008). http://foreignprophecies.blogspot.com/2008_02_01_archive. html. Diakses tanggal 22 November 2011.

Crystal, D. (2003). English as Global Language. New York: Cambridge University Press.

Durand, G. (2006). The Scenarization of the Assessment of Learning Activities using Interactive Learning Environments. Ph.D. Thesis Report. Paris: University of Savoy.

Handayani, S. (2016). Pentingnya Kemampuan Berbahasa Inggris Sebagai Dalam Menyongsong ASEAN. Ikatan Sarjana Pendidikan Indonesia (Ispi) Jawa Tengah, 3(1), 102-106. Diakses dari http://Ispijateng.Org/Wp-Content/Uploads/2016/05/Pentingnya-KemampuanBerbahasaInggris-Sebagai-Dalam-Menyongsong-Asean-Community-2015_Sri-Handayani.Pdf

Husein, A. M. \& Dewi, R. K. (2019). Peningkatan Kemampuan Pragmatis Penguasaan Bahasa Inggris Bagi Guru di Mts. Jauharul Ulum Desa Locancang Panarukan Situbondo. Dedication: Jurnal Pengabdian Kepada Masyarakat, 3(1), 39-43. DOI: https://doi.org/10.31537/dedication.v3i1.184

Koran Kompas. (2012). Minat Belajar Bahasa Inggris di Indonesia Meningkat.

Koran Republika Online. Kemampuan Bahasa Inggris Warga Indonesia Dibawah Rata-rata. Diakses di https://republika.co.id/berita/pjq0na349/kemampuan-bahasa-inggris-warga-indonesia-dibawah-ratarata

Kubanek, G. (1998). Trilingualism in Family, School, and Community. edited: Hoffman, Charlotte and Jehannes Ytsma. London: Cromwell Press Ltd.

LPM IAIN Sunan Ampel Surabaya. (2008). Modul Pelatihan Kuliah Kerja Nyata (KKN). Transformatif IAIN Sunan Ampel Surabaya (Surabaya: LPM IAIN Sunan Ampel, 2008) 
Nuraziziah, Amsaden, Jumaila, S., Yogasmara, A., Nurhaolida, \& Teluma, A. R. L. (2019). Pelatihan Berbahasa Inggris untuk Warga Sekitar Objek Wisata Desa Pasir Putih Lombok. JWD, 1(2), 202208.

O'Brien, R. (2001). An Overview of Methodological Approach of Action Research. Edited: Roberto Richardson. Joao Pesso: Universidade Federal da Paralba press.

St. Syamsudduha, S. S. \& Tekeng, N. Y. (2017). Penerapan Service Learning Dalam Pembelajaran Matakuliah Pedagogik Pada Kurikulum Pendidikan Calon Guru. Lentera Pendidikan: Jurnal IImu Tarbiyah dan Keguruan, 20(1), 1-17. DOI: https://Doi.Org/10.24252/Lp.2017v20n1a1

Susanti, N., \& Rukiati, E. (2017). Pelatihan Bahasa Inggris Bagi Karang Taruna di Desa Wisata Lombok Kulon Bondowoso. Seminar Nasional Hasil Pengabdian Kepada Masyarakat 2017 (Pp. 251-256).

Tamrin, A. F., \& Yanti. (2019). Peningkatan Keterampilan Bahasa Inggris Masyarakat Pegunungan di Desa Betao Kabupaten Sidrap. Transformasi: Jurnal Pengabdian Masyarakat, 15 (2), 2019: 61-72. DOI: https://doi.org/10.20414/transformasi.v15i2.1673

Winter, R. (1989). Learning from Experience. London: Falmer Press. 
Lampiran 1 (Angket Analisa Kebutuhan)

\section{FORUM GROUP DISCUSSION (FGD)}

\section{PEMBERDAYAAN REMAJA MASJID \\ SEBAGAI PERINTIS KAMPUNG INGGRIS \\ DI DESA KALIPAKEM, KECAMATAN DONOMULYO, KABUPATEN MALANG}

- $\boldsymbol{F G D}$ adalah sebuah diskusi yang mengedapankan penggalian informasi masyarakat sehubungan dengan permasalahan pembelajaran kebahasaan dan hal-hal yang dibutuhkan guna mencapai sukses dalam pengunaan bahasa di lingkunganya

- Isikan pendapat anda sehubungan dengan item pertanyaan berikut!

1. Seberapa pentingkah Bahasa Inggris bagi anda? Mengapa?

2. Bisakah anda mengucapkan kalimat berbahasa Inggris?

3. Dalam kehidupan sehari-hari, kapankah kiranya anda bisa menggunakan bahasa Inggris?

4. Apakah memungkinkan Desa anda dijadikan rintisan kampung Inggris? Mohon berikan alasanya!

5. Bilamana kampung Inggris di Desa anda dirintis, apakah anda bersemangat untuk mendukung program tersebut?

6. Apakah manfaat yang diperoleh bilamana kampung anda menjadi kampung Inggris? 